\title{
The Structural Characteristics and Changes of Exhibition Industry in China
}

\author{
Grant G.L. Yang $^{1 *} \quad$ Xin-Yi Yang ${ }^{2}$
}

\begin{abstract}
The development of China's exhibition industry is based on the spatial distribution characteristics of regional economic development, which shows the self-correlation and spillover effect between the exhibition industry and regional economic. The level of regional specialization begins from the industrial structure characteristic the province. This study reveals the characteristics of the industry structure and spatial differentiation pattern of China's provincial exhibition industry from the perspective of industry distribution by comparing 2017 and 2019, and finds that the current distribution of the industry sector is obviously different, the structure of the industry sector in the central and western regions is superior to the eastern part. The entropy of the national exhibition industry in different industry sectors shows increasing law, and the degree of specialization of the provincial exhibition industry in different sectors and regions prevails. Relevant adjustment paths are proposed to optimize the sector structure and spatial layout of the development of China's exhibition industry, to promote the transformation to the direction of content upgrading, to give full play to the advantages of industrial industry, and to build an industry-driven exhibition industry development model.
\end{abstract}

Keywords: Regional Industry Distribution, Structural Differentiation, Specialization Index, Industry Concentration Index, Location Entropy Index

\section{Structural Characteristics of the Development of Regional Exhibition Industry in China}

To promote the transformation of the industrial economy to the service economy worldwide. The pace of industrial restructuring, transformation, and upgrading has been accelerated in recent years. As an integral component of the service economy, the exhibition industry is an important platform to build a modern open economic system and an important index to measure the level and potential of urban and regional economic development. China's exhibition industry has become a sunrise industry in the industrial economic system and a new national economic growth point. It has become the focus of current attention due to its advantages such as vigorous growth, broad market prospect, and distinct spillover effect.

At present, the academic research on the exhibition industry mainly focuses on the following aspects: (1)From the geographical perspective, to explore the spatial distribution pattern of China's exhibition industry on different dimensions, such as national, provincial

\footnotetext{
1 Associate Professor of School of International Business, Xiamen University Tan Kah Kee College grant@xujc.com*corresponding author

2 School of International Business, Xiamen University Tan Kah Kee College

${ }^{3}$ This research is partially funded by the start-up fee for young teachers in Xiamen University Tan Kah Kee College ${ }^{\#}$ JG2018SRF08
} 
or municipal (Dai \& Chen, 2010; Li \& Yu, 2011; Zhu et al., 2015; Zhu et al., 2016), agglomeration characteristics and formation mechanism (Jiao, 2015), etc. (2)By using mathematical modeling, correlation analysis, regression analysis and other research methods to analyze the economic spillover effect of the development of the exhibition industry, and quantitatively reveals the driving effect of the exhibition industry on the regional economy (Liu \& Li, 2009; Hu \& Yang, 2006; Luo \& Luo, 2016; Gui, 2009); (3)By selecting research units such as The Yangtze River Delta ("integration"), pearl River Delta ("Greater Bay Area") and Beijing-Tianjin-Hebei ("coordinated development"), the comprehensive evaluations of the development level of the regional exhibition industry, were based on building the development capacity of the exhibition industry (Hao \& Hu, 2018; Li \& Yu, 2009; Qian, 2019), exhibition industry competitiveness and development potential, exhibition industry development efficiency indicator system (Yan et al., 2018), and empirical analysis on the comprehensive development level of regional exhibition industry (Yang, 2020; Yang et al., 2020); (4)The correlation characteristics of exhibition industry and regional related industries, and explore the correlation matching between the development level of exhibition industry and urban industrial structure $(\mathrm{Hu}, 2013$; $\mathrm{Yu}$, 2017), analyzes the interaction or driving effect between exhibition industry and regional agriculture (Zhang, 2009), industry (Yang, 2010), tourism (Zhang \& Liu, 2013) and other industrial sectors.

From the perspective of industry distribution, the existing research should investigate the internal structure, spatial differentiation, and dynamic changes of China's exhibition industry, and further strengthen the relationship between the regional exhibition industry and its advantage or characteristic industries. Besides, in China, the exhibition industry's current development needs to be further clarified in terms of regional specialization, regional comparative advantage, and brand positioning. Moreover, there is a lack of analysis on the supporting conditions of regional social, economic, geographical, and other basic elements for the exhibition industry (Yang, 2020). To accelerate China's exhibition industry's growth process, promote the exhibition industry's quality upgrading, and expand the industrial spillover effect, we still need to analyze further.

From the perspective of industry distribution, the study compares 2017 and 2019 in the aspects of industry structure characteristics in China's provincial exhibitions and spatial differentiation pattern of rapid change. To explore the exhibition industry and the regional industrial structure at the present stage in China, the unique advantage industries and the basic elements such as society, economy, geography, adaptation, and put forward the relevant adjustment path to optimize the structure of industry sectors in the development of Chinese exhibitions and its spatial distribution, giving full play to the advantages of traditional regional industry and building an industry-driven development model.

\section{Regional Exhibition Industry Distribution Index \\ 2.1 Industry Concentration Index}

The industry concentration index represents the spatial concentration of various industries in a region. It reflects the distribution of the exhibition industry in different sectors. The calculation formula of the industry concentration index is as follows (Jiao, 2015):

$$
\delta=\sqrt{\frac{\sum_{i=1}^{n}\left(S_{i}-\bar{S}\right)^{2}}{n-1}}
$$

In Equation (1), $\delta$ denotes the industry concentration index. $S_{i}$ and $\bar{S}$ respectively denotes the sessions of exhibitions held in different industry sectors and the average values; 
$n$ represents the number of sector categories in the exhibition industry. According to the industry distribution standard of exhibitions published in China Exhibition Economic Development Report (2019), the exhibition is divided into five industry categories: heavy industry, light industry, agriculture, service industry, and specialized exhibition, thus $n=5$. The closer the value is to 0 , the more balanced the exhibition industry's distribution in all regional sectors. When the value of $\delta$ is bigger, the exhibition industry's distribution varies more widely between sectors within the region, and the structure is unbalanced.

\subsection{Location Entropy}

Location Entropy is an important index to measure the location comparative advantage of industry sectors, which can reveal the specialization degree of different industrial sectors in a region, and then reflects the location comparative advantage of an industry sector in the region. The calculation formula is as follows (Liu, 2018):

$$
L Q_{i j}=\frac{a_{i j} / a_{i}}{A_{n j} / A_{n}}
$$

$L Q_{i j}$ is the location entropy of the sector $j$ in the regional exhibition industry, $a_{i j}$ is the times of exhibition that held by the sector $j$ in the region $i, a_{i}$ is the total number of times of exhibitions held in the region $i$. $A_{n j}$ is the times of exhibition that held by the sector $j$ nationwide, and $A_{n}$ is the total number of exhibitions held nationwide. If $L Q_{i j}>1$, it indicates that the distribution of the regional exhibition industry in the sector $j$ has a higher comparative advantage than the average distribution level of the nationwide exhibition industry. The sector $j$ is the advantageous sector for the development of the regional exhibition industry. The larger the $L Q_{i j}$ is, the higher the degree of specialization of sector $j$ will be.

\subsection{Regional Relative Specialization Index}

Regional Relative Specialization Index reflects the difference between the industrial specialization level of a certain region and the average level of other regions in China. It is a significant indicator to measure the industrial division or specialization level of the region. The calculation formula is as follows (Jiang, 2012):

$$
K_{i}=\sum_{j}^{n}\left|\left(E_{i}^{j} / \sum_{j} E_{i}^{j}\right)-\left(\sum_{k \neq i} E_{k}^{j} / \sum_{j} \sum_{k \neq i} E_{k}^{j}\right)\right|
$$

$K_{i}$ shows the specialization level of the regional exhibition industry, $j$ represents the distribution of a particular industry sector, $k$ represents the other regions except for region $i, E$ represents the number of regional exhibitions held in the sector $j$, the value of $K_{i}$ reflects the degree of difference between sectors in the regional industry and others in structure. The value of the regional relative specialization index is between $[0,2]$. The greater the value is, the greater difference in structure between the regional industry sector and others will be, and the higher the level of specialization will be. On the contrary, it shows that the exhibition industry's distribution structure in this region is homogeneous with the average level nationwide, and the level of specialization is not high.

In this study, the exhibition industry's data is derived from the China Exhibition Economic Development Report (2019). According to statistics, 2,099 trade and economic kind of exhibitions (covering an area of more than 20,000 square meters, excluding Hong Kong, Macao, and Taiwan) were held in China in 2019. On this basis, the 2,099 times of the exhibition will be classified into five categories: heavy industry, light industry, 
agriculture, service industry, and specialized exhibition. The distribution of different industry sectors in China exhibitions can be concluded. The final analysis further explores the provincial distribution of China exhibitions in structure characteristics, including the specialization level, the spatial differentiation pattern, etc.

\section{Structural Characteristic of the Provincial Exhibition Industry in China with the Basis of Industry Distribution \\ 3.1 Concentration Degree of Exhibition Industry Sector Structure}

According to formula (1), the basic characteristics of the concentration of the China exhibition industry in 2019 can be obtained (as shown in Table 1). In 2019, there are obvious differences in the distribution concentration of the exhibition industry of provinces in China (excluding Hong Kong, Macao, and Taiwan). The sector structure of the exhibition industry in different regions has distinct heterogeneity. According to the calculation results, Shanghai (74.08) has the highest concentration index in the exhibition industry. In contrast, Hebei (1.33) has the lowest index, which indicates a big difference in the exhibition industry's distribution structure at the provincial level, presenting a polarized situation. Among them, 9 provinces (cities) of Shanghai, Guangdong, Shandong, Beijing, Zhejiang, Xizang, Qinghai, Ningxia, and Gansu rank above the national average (the national average is 16.11), which indicates that the exhibition industry and sector structure of the above provinces (cities) is unbalanced to a certain extent. According to the original data, most provinces (cities) focus on developing the exhibition industry in the service or industry sectors, while agricultural and specialized exhibitions are lagging. The development level of the exhibition industry in different sectors is obviously different.

By contrast, the concentration indexes of exhibition of Hainan, Guizhou, Jiangxi, Shanxi, Inner Mongolia and other 22 provinces (cities, districts) are below the national average, including Sichuan, Liaoning, Hebei and other provinces (areas) obviously low (less than 4), suggesting that the province (autonomous regions) above, the distribution of different industries are relatively balanced. The original data show that most provinces (regions) have exhibition distribution in the five major categories: heavy industry, light industry, agriculture, service industry, and specialized exhibition. There is little difference in the number of exhibitions in different industry categories. However, the overall scale of the exhibition industry in the above-mentioned provinces (regions) is not small. Although the number of exhibitions does not have obvious advantages, the absolute number of exhibitions still has a certain scale. This part's results are quite different from Yang (2020) research results based on 2017.

Yang (2020) believes that China's provincial exhibition industry's development in 2017 presents a dissonance in scale and structure. The study compares the changes between 2017 and 2019 (Figure 1). The average value of the exhibition industry concentration index in 2019 (16.11) is significantly higher than the average value in 2017 (10.00). From the perspective of regional differences, in 2017, the eastern region has an absolute advantage in the exhibition industry's development scale, while the distribution structure of the industry sectors is poor. The industrial sector structure of the central and western regions is obviously better than that of the eastern region. The development difference of the exhibition industry among different sectors is relatively small. However, the exhibition industry's scale still needs to be further expanded, and the overall development level of the exhibition industry still lags far behind that of the eastern regions. According to the exhibition industry concentration index in 2019, the major 5 Eastern areas (Shanghai, Guangdong, Shandong, Beijing, Zhejiang) have shown a more obvious absolute advantage on the scale of the exhibition industry, distribution structure of industry sectors tend to differentiate, this 
phenomenon has been gradually extended to Hainan, Guizhou, Gansu, Ningxia, Qinghai, Xizang, and other regions. The distribution shows in the shape of $U$, the characteristics of low intermediate, and high at two ends.

The industrial structure of some central and western regions (Sichuan, Henan, Liaoning, and Hebei) has been significantly improved, and the developmental differences among different sectors of the exhibition industry have been significantly reduced.

Table 1. Distribution concentration of the China exhibition industry in 2019

\begin{tabular}{|c|c|c|c|c|c|c|c|c|}
\hline No & $\begin{array}{c}\text { Province/ } \\
\text { City/District }\end{array}$ & $\begin{array}{l}\text { Service } \\
\text { industry }\end{array}$ & Agriculture & $\begin{array}{c}\text { Light } \\
\text { Industry }\end{array}$ & $\begin{array}{l}\text { Heavy } \\
\text { Industry }\end{array}$ & $\begin{array}{l}\text { Specialized } \\
\text { Exhibition }\end{array}$ & Summation & $\delta$ \\
\hline 1 & Shanghai & 68 & 11 & 138 & 99 & 14 & 330 & 74.08 \\
\hline 2 & Guangdong & 83 & 10 & 119 & 98 & 20 & 330 & 70.38 \\
\hline 3 & Shandong & 26 & 16 & 75 & 54 & 8 & 179 & 31.42 \\
\hline 4 & Beijing & 58 & 7 & 60 & 39 & 12 & 176 & 29.44 \\
\hline 5 & Zhejiang & 29 & 4 & 63 & 37 & 10 & 143 & 22.10 \\
\hline 6 & Xizang & 0 & 0 & 0 & 1 & 0 & 1 & 17.66 \\
\hline 7 & Qinghai & 0 & 0 & 2 & 3 & 1 & 6 & 16.39 \\
\hline 8 & Ningxia & 1 & 0 & 2 & 3 & 0 & 6 & 16.21 \\
\hline 9 & Gansu & 1 & 1 & 1 & 4 & 2 & 9 & 16.20 \\
\hline 10 & Hainan & 4 & 2 & 1 & 5 & 1 & 13 & 15.34 \\
\hline 11 & Guizhou & 2 & 2 & 3 & 4 & 1 & 12 & 15.23 \\
\hline 12 & Jiangxi & 5 & 1 & 6 & 3 & 1 & 16 & 13.85 \\
\hline 13 & Shanxi & 5 & 2 & 5 & 5 & 0 & 17 & 13.66 \\
\hline 14 & Neimenggu & 1 & 4 & 6 & 8 & 2 & 21 & 13.39 \\
\hline 15 & Heilongjiang & 2 & 3 & 8 & 6 & 3 & 22 & 12.88 \\
\hline 16 & Guangxi & 3 & 2 & 7 & 9 & 3 & 24 & 12.29 \\
\hline 17 & Yunan & 9 & 3 & 9 & 3 & 3 & 27 & 12.02 \\
\hline 18 & Anhui & 7 & 4 & 9 & 12 & 1 & 33 & 10.01 \\
\hline 19 & Xinjiang & 7 & 3 & 8 & 15 & 1 & 34 & 9.99 \\
\hline 20 & Jiangsu & 17 & 6 & 39 & 31 & 3 & 96 & 9.10 \\
\hline 21 & Chongqing & 22 & 3 & 13 & 9 & 1 & 48 & 8.76 \\
\hline 22 & Jilin & 8 & 4 & 11 & 15 & 2 & 40 & 8.42 \\
\hline 23 & Fujing & 12 & 2 & 14 & 8 & 6 & 42 & 8.33 \\
\hline 24 & Tianjin & 8 & 1 & 24 & 7 & 2 & 42 & 7.47 \\
\hline 25 & Shaanxi & 17 & 4 & 16 & 9 & 2 & 48 & 7.04 \\
\hline 26 & Henan & 23 & 5 & 35 & 25 & 5 & 93 & 6.79 \\
\hline 27 & Hunan & 8 & 1 & 16 & 16 & 2 & 43 & 6.43 \\
\hline 28 & Hubai & 10 & 2 & 21 & 10 & 0 & 43 & 6.22 \\
\hline 29 & Sichuan & 22 & 4 & 20 & 20 & 2 & 68 & 4.24 \\
\hline 30 & Liaoning & 12 & 6 & 25 & 23 & 4 & 70 & 2.80 \\
\hline 31 & Hebei & 14 & 3 & 27 & 20 & 3 & 67 & 1.33 \\
\hline \multirow{2}{*}{\multicolumn{2}{|c|}{$\begin{array}{l}\text { Average number } \\
\text { Total number }\end{array}$}} & 15.61 & 3.74 & 25.26 & 19.39 & 3.71 & 67.71 & 16.11 \\
\hline & & 484 & 116 & 783 & 601 & 115 & 2,099 & \\
\hline
\end{tabular}

Sources: China Exhibition Economic Development Report (2019) 


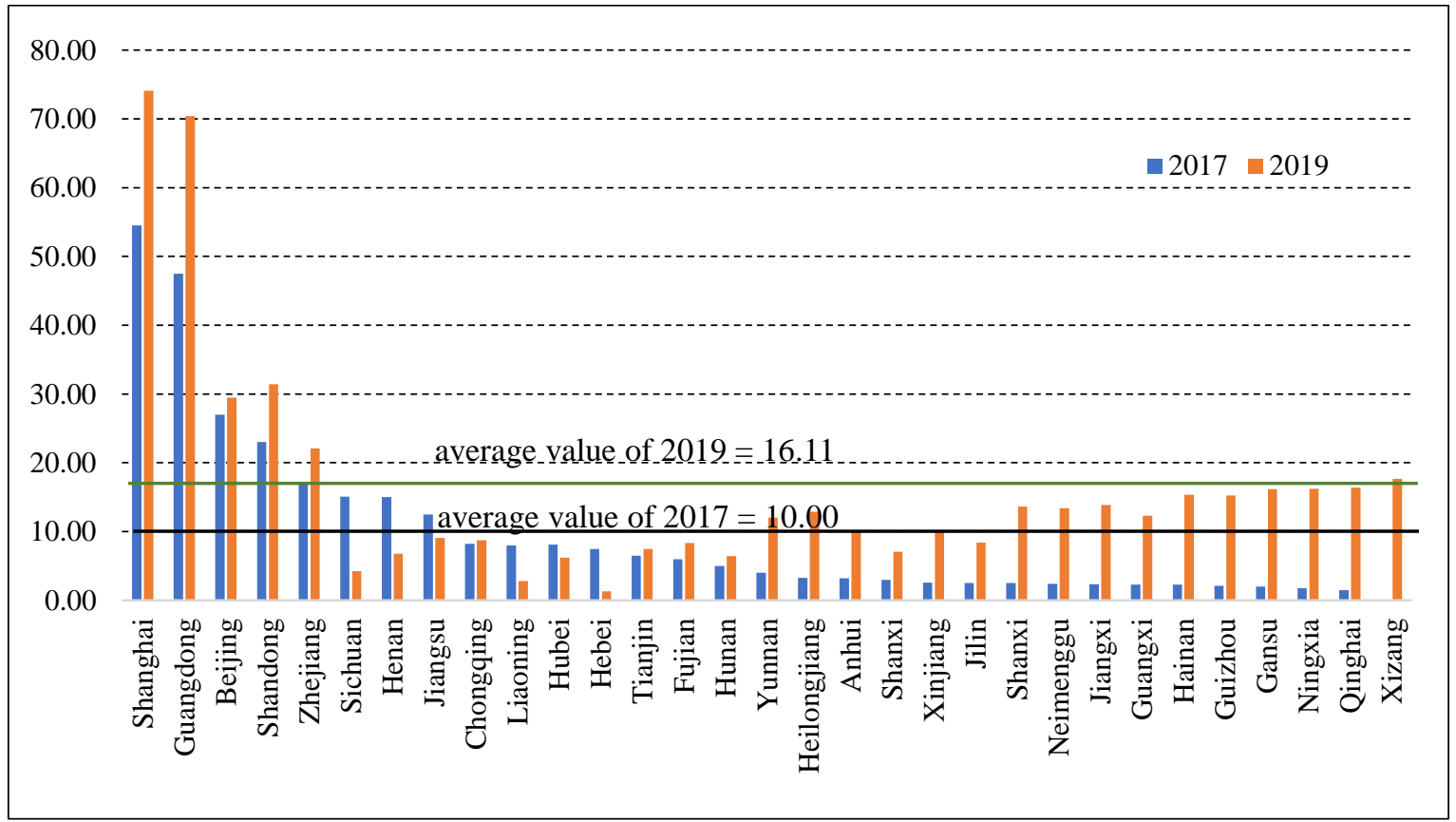

Sources: China Exhibition Economic Development Report (2019); Yang (2020)

Figure 1. Comparison of Distribution Concentration of China Exhibition Industry in 2017 and 2019

\subsection{Regional Comparative Advantage of the Exhibition Industry Sector}

To further show the regional comparative advantages of the exhibition industry in different sectors, formula (2) can be used to obtain the location entropy of different sectors of the exhibition industry in provinces of China (excluding Hong Kong, Macao, and Taiwan) to reflect the degree of specialization of the exhibition industry in different sectors of the region. As shown in Table 2, the difference location entropies of Chinese provincial exhibitions in different industrial sectors is obvious in 2019. According to the national average, the location entropies present the diminishing rule "agriculture $>$ specialized exhibition > heavy industry > service industry > light industry". This shows that the advantageous industrial sectors in the development of China's exhibition industry at the present stage are concentrated on the field of agriculture, and the "agriculture" is the key theme which selected by the most exhibitions nationwide.

In contrast, the location entropies of the exhibition industry at the national average level of different industry sectors in 2017 show a diminishing rule: "agriculture $>$ service industry $>$ heavy industry $>$ specialized exhibition > light industry". This shows that the advantageous industrial sectors in China's exhibition industry in 2019 are still concentrated on the agricultural sector, and the agricultural theme is still the key field of selection for national exhibitions. However, the ranking of specialized exhibitions and heavy industry location entropy go forward, indicating that the specialization degree of the exhibition industry is gradually improving.

From the perspective of the pattern of differentiation among provinces, the location entropies of the agricultural sector in Inner Mongolia, Guizhou, Hainan, and Heilongjiang are far higher than that in other regions, which is inseparable from the development positioning of these provinces (regions) as important agricultural provinces or commodity grain bases in China.

In terms of the service industry, Chongqing (1.99), Shanxi (1.54), Yunnan (1.45), Beijing (1.43), and other regions have high degree of sectoral specialization, but the regional 
differences are not significant. Inner Mongolia has the lowest regional entropy value (0.21). As the embodiment of the service industry, the exhibition industry has a generalization situation in various regions.

Table 2. Location Entropy Index of China Exhibition Industry in 2019

\begin{tabular}{ccccccc}
\hline \multirow{2}{*}{ Number } & $\begin{array}{c}\text { Province/ } \\
\text { City/District }\end{array}$ & $\begin{array}{c}\text { Service } \\
\text { industry }\end{array}$ & Agriculture & $\begin{array}{c}\text { Light } \\
\text { Industry }\end{array}$ & $\begin{array}{c}\text { Heavy } \\
\text { Industry }\end{array}$ & $\begin{array}{c}\text { Specialized } \\
\text { Exhibition }\end{array}$ \\
\hline 1 & Shanghai & 0.89 & 0.60 & 1.12 & 1.05 & 0.77 \\
2 & Guangdong & 1.09 & 0.55 & 0.97 & 1.04 & 1.11 \\
3 & Beijing & 1.43 & 0.72 & 0.91 & 0.77 & 1.24 \\
4 & Shandong & 0.63 & 1.62 & 1.12 & 1.05 & 0.82 \\
5 & Zhejiang & 0.88 & 0.51 & 1.18 & 0.90 & 1.28 \\
6 & Henan & 1.07 & 0.97 & 1.01 & 0.94 & 0.98 \\
7 & Liaoning & 0.74 & 1.55 & 0.96 & 1.15 & 1.04 \\
8 & Jiangsu & 0.77 & 1.13 & 1.09 & 1.13 & 0.57 \\
9 & Hebei & 0.91 & 0.81 & 1.08 & 1.04 & 0.82 \\
10 & Hunan & 0.81 & 0.42 & 1.00 & 1.30 & 0.85 \\
11 & Sichuan & 1.40 & 1.06 & 0.79 & 1.03 & 0.54 \\
12 & Chongqing & 1.99 & 1.13 & 0.73 & 0.65 & 0.38 \\
13 & Shanxi & 1.54 & 1.51 & 0.89 & 0.65 & 0.76 \\
14 & Fujian & 1.24 & 0.86 & 0.89 & 0.67 & 2.61 \\
15 & Jilin & 0.87 & 1.81 & 0.74 & 1.31 & 0.91 \\
16 & Hubei & 1.01 & 0.84 & 1.31 & 0.81 & - \\
17 & Tianjin & 0.83 & 0.43 & 1.53 & 0.58 & 0.87 \\
18 & Guangxi & 0.54 & 1.51 & 0.78 & 1.31 & 2.28 \\
19 & Yunan & 1.45 & 2.01 & 0.89 & 0.39 & 2.03 \\
20 & Xinjiang & 0.89 & 1.60 & 0.63 & 1.54 & 0.54 \\
21 & Neimenggu & 0.21 & 3.45 & 0.77 & 1.33 & 1.74 \\
22 & Anhui & 0.92 & 2.19 & 0.73 & 1.27 & 0.55 \\
23 & Heilongjiang & 0.39 & 2.47 & 0.97 & 0.95 & 2.49 \\
24 & Shanxi & 1.28 & 2.13 & 0.79 & 1.03 & - \\
25 & Jiangxi & 1.36 & 1.13 & 1.01 & 0.65 & 1.14 \\
26 & Guizhou & 0.72 & 3.02 & 0.67 & 1.16 & 1.52 \\
27 & Hainan & 1.33 & 2.78 & 0.21 & 1.34 & 1.40 \\
28 & Gansu & 0.48 & 2.01 & 0.30 & 1.55 & 4.06 \\
29 & Ningxia & 0.72 & - & 0.89 & 1.75 & - \\
30 & Qinghai & - & - & 0.89 & 1.75 & 3.04 \\
31 & Xizang & - & - & - & 3.49 & - \\
\hline National Average & 0.9787 & 1.4578 & 0.8951 & 1.1483 & 1.2977 \\
National Average & 1.1203 & 1.1653 & 0.8650 & 1.0372 & 0.9069 \\
\hline
\end{tabular}

Sources: China Exhibition Economic Development Report (2019)

In terms of light industry, the sectoral location entropies of Shanghai, Shandong, Zhejiang, Henan, Jiangsu, Hebei, Hubei, Tianjin, and Jiangxiare all greater than 1, which indicates that the exhibition industry in the above regions has a comparative advantage in the distribution of light industry. 
In terms of heavy industry, Xizang has the highest sectoral location entropy (3.49). Also, Ningxia, Qinghai, Gansu, Xinjiang, Hainan, and Inner Mongolia all have a location entropy higher than 1.33. However, the heavy industry sectors in Shanxi, Hunan, Heilongjiang, Shaanxi, Jilin, Liaoning, and other provinces with strong traditional industrial bases are not significant, indicating the inapparent development of exhibition industry's regional advantages. According to the original data, in 2019, most "industrial type" exhibitions in the above regions focus on traditional industrial fields such as automobile, equipment manufacturing, energy, chemical industry, mechanical metallurgy, etc. However, high-tech industries such as IT, software, and automation have gradually produced spillover effects and expanded traditional heavy industry to other fields. This shows that the industrial base development in the region is no longer an important supporting condition for "industrial type" exhibitions.

With a location entropy as high as 4.06, Gansu province occupies an absolute advantage from the special exhibition perspective. Also, the location entropies of special exhibitions in Qinghai (3.04), Fujian (2.61), Heilongjiang (2.49), Guangxi (2.28), and Yunnan (2.03) are also much higher than 1. Among them, in addition to Fujian's advantages in the opening to the outside world and creating conditions for the development of special exhibitions on import and export trade, Qinghai, Heilongjiang, Guangxi, and Yunnan are all frontier provinces (regions), and their good geographical locations also provide important conditions for special exhibitions.

From the perspective of the differentiation of the eastern, central, and western regions, the location entropies of the eastern region in the service industry and the special exhibition industry are higher than 1 , which is still the advantageous sector in the development of the exhibition industry in eastern region. It is closely related to the good economic foundation, superior location conditions and strong urban support in eastern region.

Overall, the eastern region of developed market economy, urban comprehensive serviceability, show business market demand, in the tourism and leisure, health, logistics transportation, insurance, financial, such as advertising media, real estate services development momentum is strong, and for regional exhibition "service" and the special resources, the development of the exhibition to provide important background for the development of the national exhibition organizers take the lead.

The central region still has comparative advantages in agriculture and heavy industry and is professional in labor division in the national exhibition industry, mainly due to its strong industrial and agricultural, historical foundation. The central region has traditional advantageous industrial sectors such as automobile production, equipment manufacturing, metallurgy and casting, energy and chemical industry, construction machinery, electric power, and automation, and is distributed in the main grain-producing areas such as the northeast plain and the middle and lower Yangtze River plain. Harbin, Changchun, Shenyang, Taiyuan, Wuhan, Changsha, and other industrial cities are key positions and important heavy industry and commodity grain bases in China, which provide natural and superior factors for regional exhibitions of "agriculture" and "heavy industry". The central region is an important potential region for the integrated development of the exhibition industry and traditional advantaged industry in the future.

In the western region, the location entropies of the service industry, agriculture, and heavy industry are all higher than 1 , which indicates that the exhibition industry has high degree of specialization in the above-mentioned three industry sectors and is the advantageous sector in the development of regional exhibition industry. In recent years, the state has strengthened strategic investment in western development, promoted infrastructure construction, and driven industrial transformation and upgrading. All these measures have 
promoted the development above. Emerging exhibition cities such as Chengdu, Chongqing, Xi'an, Kunming, Lanzhou, and Urumqi have risen rapidly, becoming important spatial fulcrums for the exhibition's development industry in the western region. With the exhibition industry as the exchange platform, we will further accelerate regional service industries' growth and activate the development vitality of regional traditional industries such as agriculture and heavy industry.

\subsection{Characteristics of Structural Differences in the Distribution of Sector in Provincial Exhibition Industry}

To further reflect the degree of differences in the exhibition industry sector structure among provinces in China, formula (3) is used to obtain the regional relative specialization index of the exhibition industry among provinces (cities and districts) (as shown in Figure 2 ), and reveal the differences in the exhibition industry sector structure among provinces (cities and districts) and their degree of specialization.

The regional differences in the level of specialization of China's exhibition industry are obvious among provinces. If the country is divided into three blocks, the relative specialization index of the first block is above 0.40, including 9 provinces (cities and districts) Xizang, Gansu, Qinghai, Hainan, Inner Mongolia, Chongqing, Yunnan, Ningxia, and Tianjin, with the highest index of Xizang (1.428). This shows a great structural difference between the exhibition industry's distribution structure in the above provinces (regions) and other provinces (cities, regions), and the professional level of the exhibition industry is relatively high. According to original data, the provinces' exhibition industries (areas) above more focus on heavy industry than light industry. Other industry sectors distribution is less but not in a blank state. It is also related to the province (area) as a frontier province (area), a good geographical location for the special exhibition.

The second block includes 13 provinces (regions), including Xinjiang, Guangxi, Guizhou, Heilongjiang, Shaanxi, Fujian, Anhui, Jilin, Shanxi, Beijing, Hubei, Sichuan, and Shandong. The index of relative specialization of the exhibition industry region is between 0.20 and 0.40 . Most of the above provinces (regions) are in the central and western regions. With the transformation and upgrading of industrial structure and exhibition venues and facilities, the regional exhibition industry has grown rapidly in recent years. According to the original data-trace, most regions' exhibition industry is distributed in all industries and sectors. The exhibition industry's distribution structure is similar to the national average level to a certain extent, and the regional specialization degree has decreased compared with the first block.

The third block includes Jiangxi, Zhejiang, Hunan, Jiangsu, Liaoning, Shanghai, Guangdong, Hebei, and Henan. Among them, Henan has the lowest relative specialization index, which is only 0.0419 , indicating a small gap between the exhibition industry's sectoral distribution structure in the above-mentioned regions, and the national average level is a similar structure phenomenon. The sectoral specialization level of the exhibition industry is low. Most of the above-mentioned areas are in the eastern part of China or economically developed regions in China's central and western parts, with relatively superior geographical location, economic foundation, and policy environment. The overall development level of the exhibition industry is in the leading position in China. Distribution from the industry point of view and the individual regions, in 2019, the regional exhibition organizers in the five major industry sectors' distribution have obvious advantages in absolute numbers. The development level of industry sectors in Shanghai, Guangdong, Hebei, Henan, and other provinces (municipalities) keeps pace with each other, the 
comprehensive features of that are prominent, the sector division of provincial exhibition is not clear.

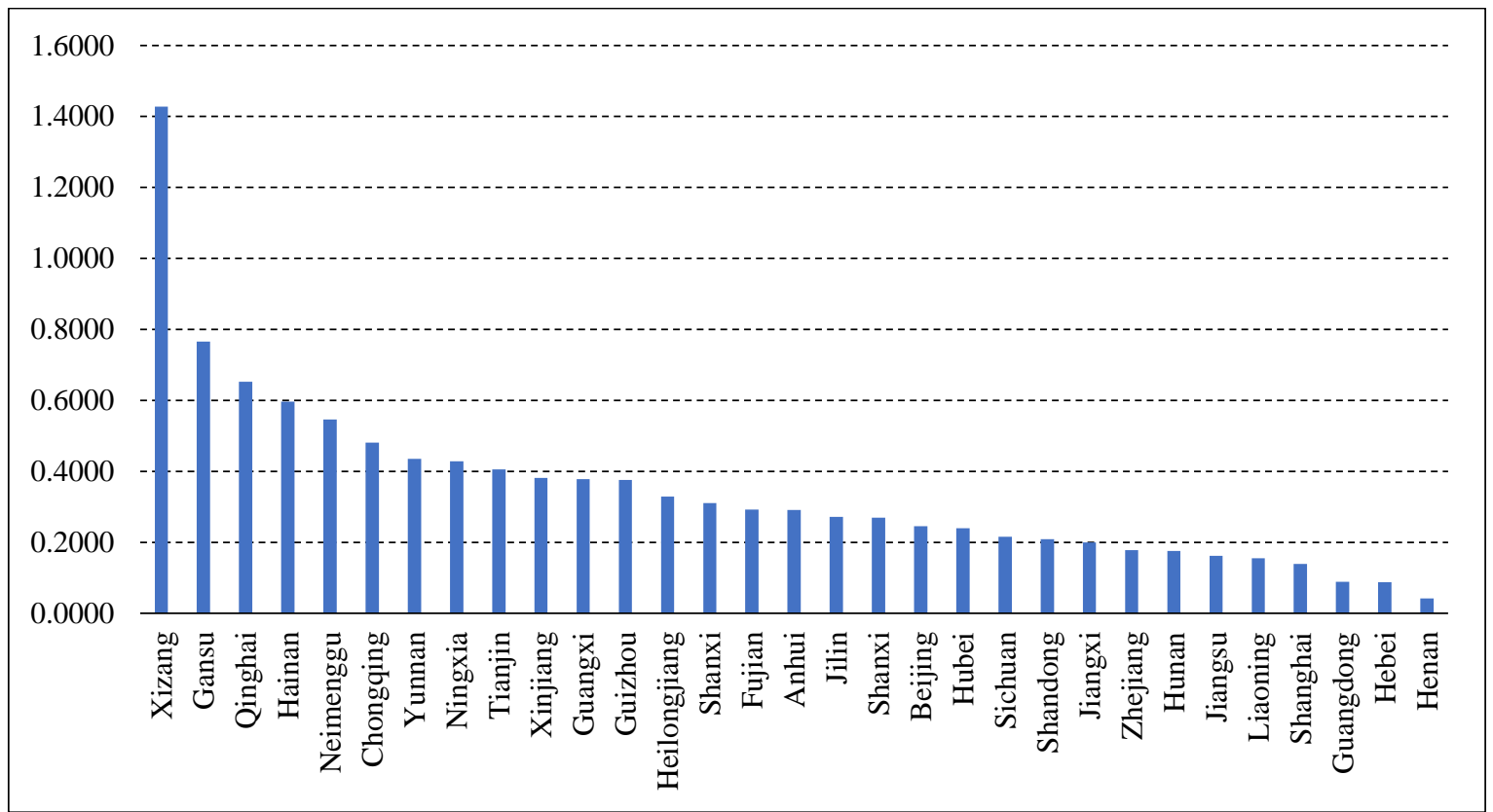

Source: China Exhibition Economic Development Report (2019)

Figure 2. Relative Specialization Index of Exhibition in China's Provinces

(Cities and Districts) in 2019

\section{The Adjustment Path of Industry Structure Optimization in China Provincial Exhibition Industry}

China's exhibition industry has obvious spatial clustering characteristics in spatial distribution and industrial structure. The exhibition industry's development level shows a diminishing law from east to west. High-level exhibition industry areas are mainly concentrated on east China, south China, north China, and southwest China. In Shanghai, Guangzhou, Beijing, Chongqing as the center of north, south, east, west, four belts of exhibition economy have been formed. Furthermore, there are also the Bohai Rim, the Yangtze River Delta, the Pearl River Delta, and the Chengdu and Chongqing regions. The number of exhibitions and the distribution of exhibition halls in these regions is relatively concentrated, and the exhibition industry and sector structure are uniforms, forming a relatively stable exhibition industry chain. The exhibition industry development trend of the spatial distribution and structural differences result from the joint action of many factors. These factors include regional social and economic conditions, the related policy, and the market environment. The regional social and economic factors, including population, industry, traffic, economic extroversion, and public facilities construction, especially closely related to the development level of tourism and transportation. Suggestions for the future structural optimization of China's provincial exhibition industry are as follows:

\subsection{Tailor to Local Conditions, Take Full Regional Advantages and Build Distinctive Exhibition Brands}

The benefits, including characteristic industries, are the basis and theme of the regional exhibition industry's development and important indexes to measure the local exhibition industry's development potential. Future exhibition organizers in China should base on 
regional advantages or characteristics of industrial clusters to build accord with the characteristics of region or city exhibition brand, forming the development pattern of "one province with a brand" and "one city with a distinct characteristic."

The traditional mining industry development advantages and potential promote regional exhibition organizers and its adaptation degree of the traditional advantage industry and strengthen regional exhibition brand specialization. By tapping the development advantages and potential of traditional industries, the regional exhibition industry should enhance to match its conventional competitive industries. The specialization of regional exhibition brands should also strengthen. For example, the eastern region's advantages lie in location, industry, policy, science and technology, environment, and other conditions. Based on the advantage of tourism, health, trade, logistics, finance, real estate, advertisement, education, high-technology industry, we need to build a brand exhibition centered on services and characteristics, such as improving exhibition function's strength.

The characteristic exhibition gathering area and the coastal exhibition industry develop intensive belt forms and adapt to the regional industrial and economic development levels. As for the Midwest, the district can rely on traditional agriculture, industry, and other industrial bases. In these places, "One Belt and Road" and other national strategies can be docked, with the regional characteristic of agriculture, equipment manufacturing, energy, and chemical industry, metallurgical machinery, and other traditional advantageous industry sectors to support. Guided by market demand, we need to accelerate the "agriculture", "heavy industry" and "national import and export trade" in the characteristic such as exhibition brand, and constantly to promote the brand influence of the exhibition, and to drive the regional traditional transformation and upgrading of industrial structure. Finally, the coordinated development of regional exhibition organizers and traditional superior industry can be achieved. An emerging exhibition industry will be built in central and western China.

\subsection{Extension of Exhibition Industry Chain with Deep Integration of Industry}

Industrial association and integration are essential paths to drive the upgrading of regional industrial structure and to extend the industrial chain's development and the main theme of economic development. Like a sunrise industry in China, the exhibition industry has strong cross-border nature, great relevance, and high spillover benefits. It is an important choice for China to transform its economic growth mode and cultivate new economic forms. Specifically, relying on the exhibition's exchange platform function, exhibition organizers should organically integrate agriculture, industry, service industry, and other three industries and continuously expand and innovates the theme and product series of regional exhibitions. For example, in the eastern region, the integration between the exhibition industry and tourism, health, culture, sports, leisure, finance, and other competitive industries can strengthen the exhibition industry chain cluster's growth. The central and western regions can actively explore the integration of the exhibition industry with traditional industries such as agriculture, energy, machinery, chemical industry, machine tool, and metallurgy to continuously improve the space of traditional advantageous industries in the region. In the future, exhibition organizers will actively promote the exhibition industry's organic integration with strategic emerging industries such as new technology, new energy, new materials, environmental protection, and health. Organizers will lead the innovation, transformation, and upgrading of China's exhibition projects by launching special exhibitions on new energy vehicles, building materials, high and new technologies, green environmental protection, and medical health in due time. 


\subsection{Coordinate the Development of Regional Exhibition Industry and Spatial Distribution}

As for China's future exhibition industry, exhibitors need to optimize the exhibition's spatial distribution pattern and promote regions' harmonious development. At present, China's exhibition industry's development still faces the reality of repeated exhibition themes, the unclear regional division of labor, and the large gap.

The absolute number of exhibitions in the vast central and western regions and border provinces (regions) is obviously too small. The growth of the exhibition industry is far behind. Unbalanced development has become a formidable barrier to the overall strength improvement of China's exhibition industry. Particularly, exhibition organizers in the eastern region should make full use of the advantages of economy, location, talents, policies, and other conditions, basing on further creation of the high-quality goods exhibition brand, improving the capacity of the economic contribution of regional exhibition organizers and the leading role, play to Shanghai, Beijing, Guangzhou, Shenzhen, Qingdao, Nanjing, Xiamen and show the center of the city engine effect, and actively cultivate Yiwu, Linyi, Weifang, Kunshan, Shunde, Langfang city, Jinjiang and other small and medium-sized exhibitions; At the same time, we will guide Shanghai, Beijing, and Guangzhou to follow the road of branding, integration and high-end development, improve the international level of the exhibition industry, and make the exhibition industry a new pillar industry leading the regional economic development. Exhibition organizers in the central region, with the aid of regional traditional industry advantage, create traditional exhibition brands such as agriculture, industry, optimize the regional division of labor, accelerate the growth of emerging exhibition cities such as Harbin, Changchun, Zhengzhou, Wuhan, Changsha, Hefei, Nanchang, promote the collaboration of central region exhibition organizers, and make it perform the function of transferring in the region. In the western region, exhibition organizers can further strengthen regional catch-up effects and invest resources in personnel training, facilities construction, capital investment, policy-making, and other aspects. With Chengdu, Chongqing, Xi' an and other cities with developed exhibition industries as the fulcrum, we will promote the rise of potential exhibition cities in Urumqi, Lanzhou, Hohhot, Kunming, Nanning, and Guiyang, to support the complementarity between cities and unleash the development potential of the regional exhibition industry.

\subsection{Optimize the Structure of the Departments of Industry}

The distribution structure of industry sectors is an essential factor affecting the exhibition industry's comprehensive economic benefits. Results of the study show that there is still a phenomenon of the dissonance between scale and structure in the development of exhibitions in China. In most provinces and cities, organizers only pay attention to the increase of the absolute number of exhibitions but ignore the structural proportion between different industries, which induces the block to promote the exhibition industry's comprehensive benefits. This phenomenon is especially prominent in Shanghai, Beijing, Guangdong, Shandong, Zhejiang, and other provinces (cities), where the exhibition industry has developed dramatically. In the future, while ensuring the absolute growth of exhibitions, organizers should promote the transformation from quantitative expansion to qualitative improvement to make up for the developmental defects of some sectors of the exhibition industry by utilizing the advantages of traditional industries and integrating the development of innovative exhibition industry with related industries. For example, organizers in the eastern region can appropriately tap the potential of holding exhibitions in agriculture, industry, and other fields. Those in the central and western areas can further increase the scale of service industries and special exhibitions. To further unleash China's exhibition 
industry's development potential and improve the exhibition economy's development quality, it is necessary to rationally allocate the exhibition industry's investment structure in different regions and sectors as well as to guide the transformation of the exhibition industry's economic growth pattern from scale to structure.

\section{References}

1. Dai, G. Q., \& Chen, Xin (2010). The temporal and spatial characteristics of Chinese exhibition industry from the perspective of the Internet. Geography Studies, 29(12), 2143-2154.

2. Gui, J. Y. (2009). Research on the relationship between exhibition industry and Guangdong economic interaction development (unpublished master thesis). Guangzhou: Guangdong University of Foreign Studies.

3. Hao, X. L., \& Hu, P. (2018). Evaluation and analysis of urban exhibition industry development ability. Tourism Research, 10(2), 26-36.

4. Hu, P., \& Yang, J. (2006). An empirical study on the economic pull effect of exhibition industry. Journal of East China normal University (philosophy and Social Sciences Edition), 5, 20-23.

5. Hu, Y. T. (2013). Spatial and temporal pattern of urban exhibition industry in Yangtze River Delta and its correlation with urban industrial structure: Take 2008-2012 as an example (unpublished master thesis). Shanghai: Shanghai Normal University.

6. Jiang, Z. L. (2012). Spatial division of labor, geographical concentration, and spatial optimization countermeasures in the manufacturing industry of Wuhan urban circle (unpublished master thesis). Wuhan: Central China Normal University.

7. Jiao, P. (2015). Research on spatial agglomeration and influencing factors of exhibition industry in China: Empirical evidence from 76 cities in 31 provinces and cities in China (unpublished master thesis). Beijing: Beijing Second Foreign Language Institute.

8. Li, L., \& Yu, J. X. (2009). Comparison of regional competitiveness of Pearl River Delta and Hong Kong exhibition industry. International Economic and Trade Exploration, 25(12), 51-56.

9. Li, W. X., \& Yu, Dan (2011). Geographical study of regional spatial layout of domestic exhibition industry. Journal of Capital University of Economics and Trade, 13(5), 4046.

10. Liu, D. K., \& Li, M. (2009). Analysis of the economic impact of exhibition industry on Beijing. Journal of Beijing Second Foreign Language Institute, 31(7), 6-12.

11. Liu, S. S. (2018). The position entropy analysis of the industrial sector in the northcentral and southern regions. Liaoning Economy, 9, 66-68.

12. Luo, Q. J. \& Luo, Q. W. (2016). Research on the relationship between provincial exhibition industry and economy and its spatial spillover. Geoscience, 36(11), 17291735.

13. Qian, Y. Q. (2019). Study on the evolution characteristics and optimization countermeasures of exhibition space layout in Beijing, Tianjin, and Hebei (unpublished master thesis). Tianjin: Tianjin Commercial University.

14. Yan, H. L., He, B., Xu, F., \& Bai, J. (2018). A study on the efficiency of urban exhibition industry in China (based on a DEA analysis of 30 provincial capitals. Tourism Forum, 11(3), 17-24.

15. Yang, G. L., Lu, Y. L., Yang, J. H., \& Huang, K. T. (2020). On the Competitiveness of Xiamen Exhibition Industry from the Comprehensive Index of the Development of China Urban Exhibition Industry. Mice Prospects, 1(2), 1-13.

16. Yang, X. H. (2010). Development and Research of Shenyang Industrial Exhibition. 
Northern economy and trade, 2, 37-38.

17. Yang, Y. B. (2020). The structure of China's provincial exhibition industry is different in characteristics and its optimization path based on the distribution of the industry. Enterprise Economy, 1, 73-79.

18. Yu, Y. F. (2017). Analysis of the correlation between urban industrial structure and exhibition industry development. Business Studies, 24(4), 135-148.

19. Zhang, Y., \& Liu, H. L. (2013). The interactive study between the conference and exhibition industry and the tourism industry is analyzed by taking the Beijing tourism trade fair as an example. Business Economy, 13, 52-54.

20. Zhang, Y. Q. (2009). On the role of agricultural exhibition in promoting the development of modern agriculture in Shandong. Chinese High-tech Enterprises, 20, 82-83.

21. Zhu, Q. J., Deng, H. B., Wang, Y., Cha, Y. Y., \& Zhou, L. (2015). The distribution characteristics of exhibition industry in China at different spatial scales. Journal of Nanyang Normal University, 14(12), 39-42.

22. Zhu, Q. J., Lu, L., Wang, Y., \& Huang, J. F. (2016). The spatial distribution of exhibition industry in China and its influencing factors. Journal of Anhui Normal University (Natural Science Edition), 39(01), 77-82+88.

(Editors: Lin, Min-Jing \& Yan, Jia-Yi) 